実験的䫟関節突起骨折の治瘾過程に関する組織学的研究

\author{
福井正義*・島原政司*・横矢 喬* \\ 小野尊睦 $* *$
}

\title{
Histologic study of healing process of the mandibular condyle after unilateral condylotomy in the rat
}

\author{
Masayoshi Fukui* - Masashi Shimahara*. Takashi Yokoya* \\ Takatoki ONo**
}

緒言

顎関節突起骨折は，下顎骨骨折の中でも非常に頻度の 高いものである．顎関節突起は，機能的には顎運動をつ かさどる重要な支点となり，形態的には顔面の対称性に 影響を与えることなどから，その治療にあたっては下顎 骨骨折の中でも特に注意を要する部位と云える.しかし ながら䫇関節突起骨折の治療法が確立されていない現 在, 治療に際し，しぱしば困惑させられる場合が少なく ない.

罰関節突起骨折の治療法は, Eubanks ${ }^{1)}$ らの推奖する 保存的療法と, Thoma ${ }^{2}$, Robinson and Yoon ${ }^{3)} ら$ の推 奨する観血的療法に分けることができる.

現在治療法がこのように一様でない理由としては, 関 節という形態的にも，機能的にも非常に複雑な場所であ り，またその予後においても問題を残すことが多い場合 があるためである．一方組織学的にも骨折治嘴過程が未 た充分に把握されていないことからも，な扣いっそう問 題を複雑にさせているようである．そこでこうした問 題点の解明を目的とし，顎関節突起骨折を実験的に葓起 し,さまざな観点から顎関節突起骨折について検討が なされている.

組織学的, 形態学的に顎関節突起骨折治瘾過程につい ての報告は, Gilhous Moe ${ }^{4)}$ が guinea pig を用い, 買 関節突起骨折を実験的に若起し, 回復時に打ける関節軟 骨層の細胞反応を観察するために $\mathrm{H}_{3} \mathrm{TDR}$ を使用し，患 側, 非患側下顎頭に打ける細胞の活動性について述べ,

* 大阪医科大学口照外科学教室（主任 : 古川哲夫助教授）

** 京都大学医学部口腔外科学教室 (主任：小野然睦教授)

* Department of Oral Surgery, Osaka Medical College (chief : Assist. Prof. Tetsuo Furukawa)

** Departmen of Oral Surgery, School of Medicine, Kyoto University (chief : Prof. Takatoki Ono.) 受付 昭和47年11月27日
Sprinz (1967) ${ }^{5)}$ は rat に顎関節突起骨折を惹起し，骨 折が咀嚼機構におよぼす影響を観察するととともに，他 方顎関節突起骨折回復過程における骨折部の組織変化に ついて説明している.

すなわち術後 8 日目に一時的咬筋の不均衝が見られる。 また軟骨性仮骨，線維性仮骨による骨折部の組織的回復 は7 日目より 10 週目に観察され，さらに軟骨組織の出現 については，その出現場所に注目し，その部骨折片の転 位，組織圧迫などの物理的因子が循環系に影響を㧊よぼ し，結果的には軟骨組織の発生につながると説明してい る、また Sprinz $(1970)^{6)}$ は，ほほ成熟した rat の額 関節突起頸部に骨折を惹起し, 関節頭側の外側翼突筋を 分離した. 術後 8 週目には, ほぼ正常な買関節突起の形 態と, 骨膜の再生, 外側翼突筋の完全な再形成を観察し ている. 肉眼的所見では，顎関節突起の大きさ，上行枝 の高さを計測し，いすれもの縮小を見ている. Anderson $^{7)}$ は成長期の犬の顎関節突起骨折による影響を調 べるために，顎関節突起頸部に骨折を䒩起し，その後 wire にて固定した結果，59週までに，骨折部の回復と 下顎の正常な発育が認められたと説明している.

また顎関節突起骨折の治療法が治撚過程にいかなる 影響をもたらすかについての研究は次のよらである. Walker ${ }^{8)}$ は成長期のサルに顎関節突起骨折を惹起し, その結果, 外科的あるいは保存的処置のいずれにおいて も顎関節突起の再形成を認めている.そしてこのような 再形成は，早期顎運動により治癒過程に相違があったか

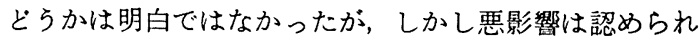

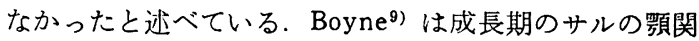
節突起に osteotomy を惹起し, 治療法を外科的処直群, 保存的処置群，そして無処置群に分類し治瘾過程を観察 した結果，いずれの処置方法にても治獶過程に大差は認 められなかったことから，小児の Condylar fracture は 骨折治癒状態, 顎関節突起発育からも保存的に治療され 
るべきであると説明している。

著者らも先に rat の頡関節突起に実験的に骨折を藻起 乙, 治療法学骨折片直接固定群, 間接固定群, 非固定群 に分類し観察した結果を報告した ${ }^{10)}$ ，すなわち骨折部に は種々の程度の変形治瘾を認めなか゚らも䫇運動が維持さ れており，また組織学的には関節㔖起には関節軟骨も見 られ，ほ添正常構造が観察されるものも認められた. し か乙実騟期間が 3 週間と短期間で，実験操作も一様でな かったことから，今回は主に䫟関節突起骨折の組織学的 治婘過程を観察する意味から，ウイスター系ラットの頪 関節突起頸部沉，可及的同一条件，同一形態の骨折を㳴 起し，衍後，整復，固定（外力）を行ならことなく，実 験期間12週にわたり経時的に骨折治瘾状況の組織学的観 察を行なった。

\section{実 験 方 法}

実験動物としては体重 $130 \mathrm{~g}$ 前後のウイスター系ラッ ト67匹を用いた．Nembutal 腹腔内注射に上り全身麻醉 を行ない，耳前部を苟毛，消毒の後，長さ約 $1.5 \mathrm{~cm}$ の頓 部耳前切開を入れ，皮膚，皮下，筋肉組織を䟝離し䫇関 節乫起を露出した. No. 700 フィッシャーバーにて顎関 節突起頸部を水平方向に離断した（写真 1 ). 骨析線の 位置，方向は各動物なるべく一定となるように行なった。 その後創面に抗生物質を挿入し，筇層縫合，皮層縫合を

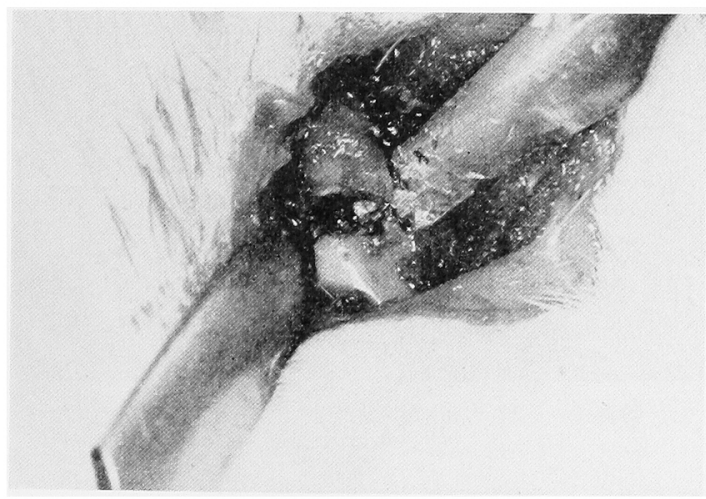

写真 1 顥関節知起を完全䧺断

行なった．笑験期間は 1 週間（15匹）， 2 週間（13匹）， 3 週間 (24匹)，12週間（15匹）とし，突験期間終了は 屠殺，断頭し，10\%ホルマリン水溶液にて固定し，パラ フィン包埋切片標本を作製 し, Hematoxillin-Eosin 染 色を行ない鏡検した.

\section{実 験 成 績}

\section{1 週間後所見}

両骨折片断端部には強度の炎症性細胞浸潤が見られ， 懐死組織が骨体側骨折片内外側飞存在し，異物巨細胞も その周辺に認めた，一方骨折片に接っして，特に骨体側

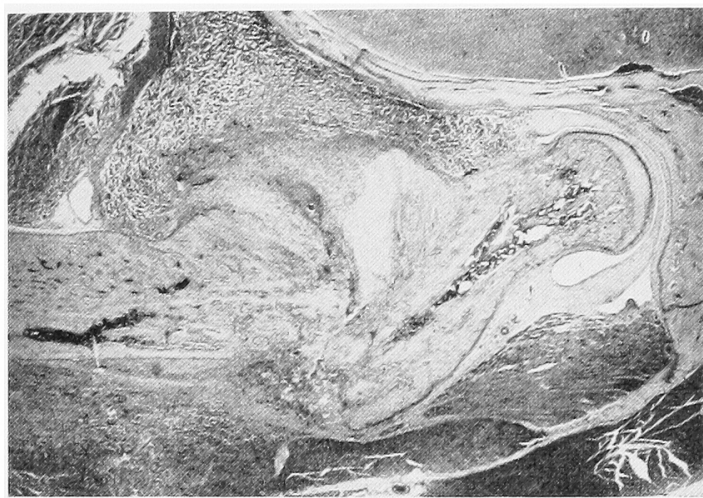

写真 2 両骨折片内側に僌骨組織吕出現 1 週間後 $\times 10$

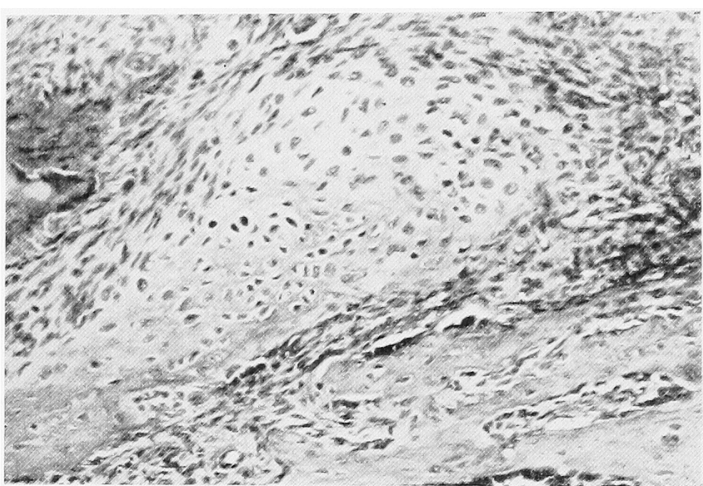

写真 3 骨折片飞近、場所では新生骨梁の形成. 1 週間後. $\times 100$

骨折片内側，あるいは下顎頭側骨折片内側に一群の軟骨 組織の出現が認められた（写真2）。軟骨組織周辺には 線維性結合組織が密に充满し, 結合組織細胞との境は, 紡鍾形，円形を示するのが見られ，軟骨芽細胞への移行 像が認められた。ささらに增殖中の軟骨組織は, 嶋状, 帯 状を呈し，幼弱な新生骨梁を形成しつつ市るようであっ た.すなわち endchondral ossification が著明であった (写真 3 ).

\section{2 週間後所見}

両骨折片断端部の吸収が進み丸味を帯びていた，浮腫， 血塊は減少ないし消失していたが，特に断端部周辺には 炎症性細胞浸潤が残存していた，この時期に打いても両 骨折片断端周辺には骨組織の新生は認められなかった。 骨体側骨折片内側，下顎頭側骨折片内側飞発現した一群 の軟骨組織は，内方に笑出した瘤状の增殖が著明であ。 た（写真 4)。一方骨折片に近い場所では，仮骨形成が， すなわち線維性結合組織一軟骨組織一海綿様骨梁材一幼 弱新生骨梁へと分化が顕著となっていた（写真 5)，仮 骨形成は，軟骨組織を形成しないで骨基質化を行なら intramembranous ossification（直接化生）飞上り新生 骨梁が内方肥厚を行なっている像をも認めた。

\section{3 週間後所見}




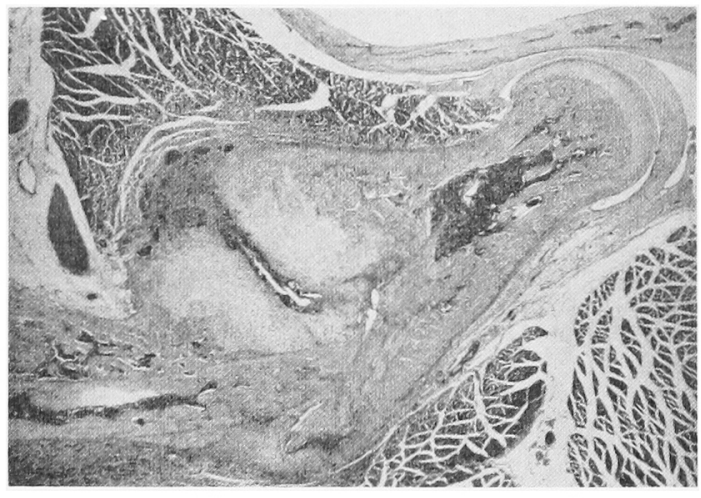

写真 4 軟骨組織の堌殖による肥厚. 2 週閒後 $\times 10$

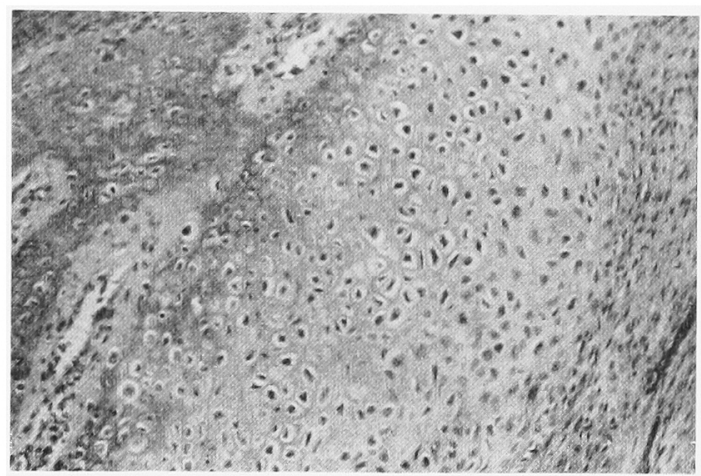

写真 5 骨折片附近に叔引る軟骨性化骨. 2 週間後 $\times 100$

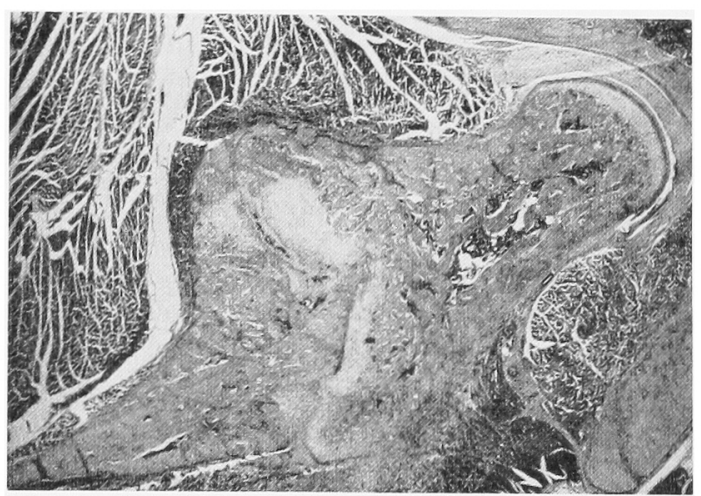

写真 6 両骨折牌は橋梁状に仮骨形成, 即ら内部改造が行 なわれ，新生骨梁にて結合. 軟骨組䅗は新生骨に て包合されている. 3 週間後 $\times 10$

骨体側骨折片断端部は吸収が完全に行なわれ新生骨梁 にて置換されている症例，また吸収されつつあるが断端 部に新生骨染の出現は認められない症例があった，一方 下靧頭側骨折片断端部はいずれも完全に吸収され，新生 骨梁が添加されていた，両骨折片内側，あるいは一部外 側から発現した新生骨梁は，術後14日目までは骨体仅対 し外方に見られたが，21日目では橋梁状に接合し山状に
肥厚し内方への突出が見られた（写真6）。すなわら肥 厚した部分は，多くの症例において外側から順次 intramembranous ossification, endchondral ossification なとの仮骨様式機転により周囲から骨梁材の添加が行な われつつ, 内部に軟骨組織，線維性結合組織を被包する ごとき像を呈していた（写真7）。こうした内部楧造の 改造が進み，両骨折片は新生骨梁にて骨性瘾合が終了し ている症例もあった，骨梁增殖が比校的早期汇行なわれ

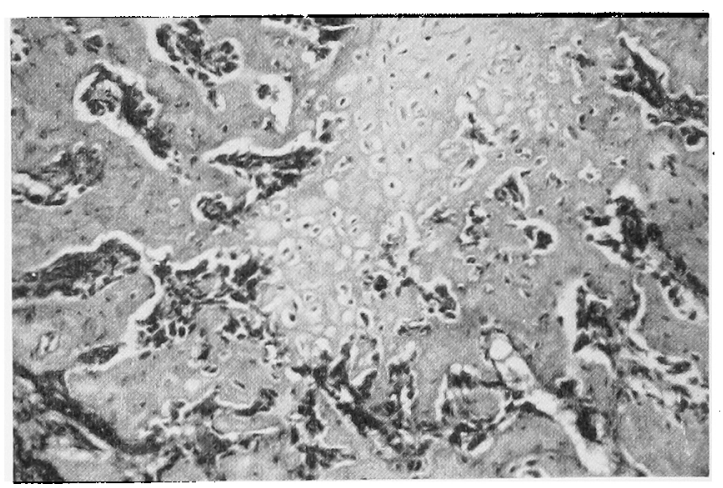

写真 7 軟骨性化骨. 新生骨梁の形成. 3 週間後 $\times 100$

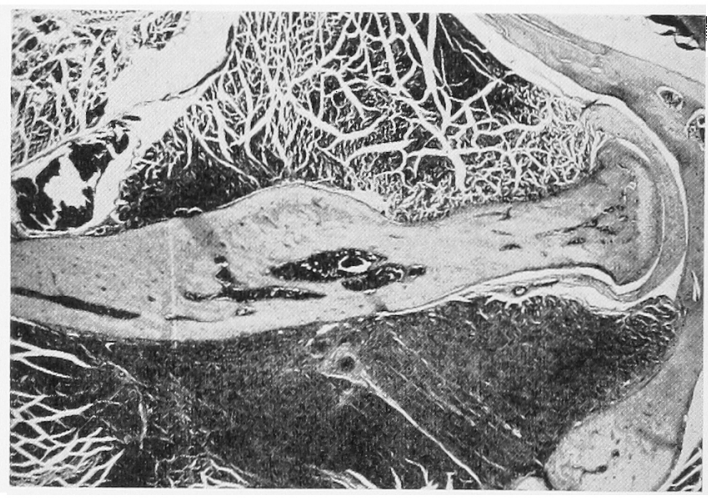

写真 8 形態は不規則であるが，両骨折片は完全骨性 結合. 12 喦間後 $\times 10$

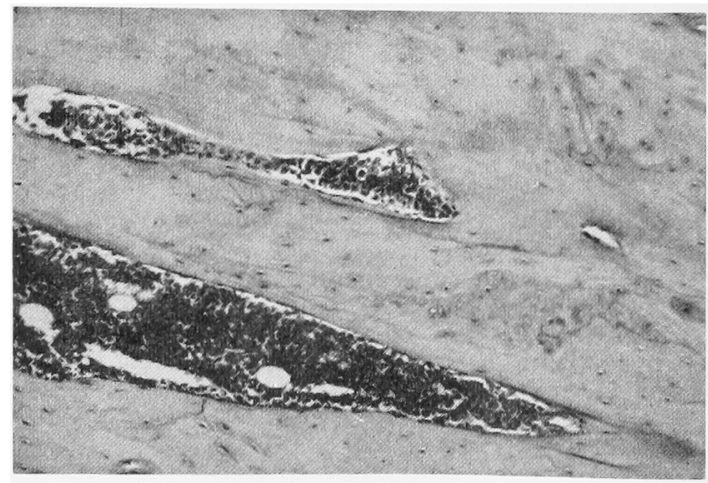

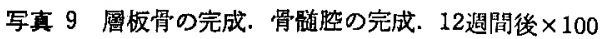


たと考えられる部位では，骨髄腔も次第に形成されつつ あるようで，その中には骨芽細胞が髅腔壁に沿って規則 的に配列し，骨髄細胞，赤血球が認められた。

\section{2週間後所見}

両骨折片は完全に骨性瘺合しているが，未だ肥厚が残 りその形態は不規則であった（写真 8)。しかしその表 層及び深層はすでに基礎骨板ができ，さらに Havers 氏 管をとり囲むHavers 氏骨板なとの骨板系を境とする 接合線が認められ，いわゆる層板骨の形成がなされてい た．骨膸腔には骨髄細胞，赤血球が充満した正常な骨髄 像を示していた（写真 9).

$$
\text { 総括 }
$$

以上頡関節突起骨折治瘺過程の経時的変化につき，各 実験期間別に観察され得た標本を模式図に示してみると 写真10〜13のようにであった.

術後 1 週間目の模式困（写真10）について見ると，症 例 122 に見られるごとき外方偏位は 1 例のみで，他は全 例内方偏位を示していた，術後 1 週目に出現を見た軟骨 組織は全て両骨折片内側飞認められ，それを線維性結合 組織が被包するがごとき所見を現わしていた. 2 週目（写 真11）になると，軟骨組織の增殖が著しく，内方に瘤状 の肥厚を現わしていた。－一方骨折片断端部では仮骨形成 が進行し，一部幼弱新生骨梁の添加が認められている場

Diagram of the repair of Subcondylar fractures in young rats. (1 weeks after operation.)

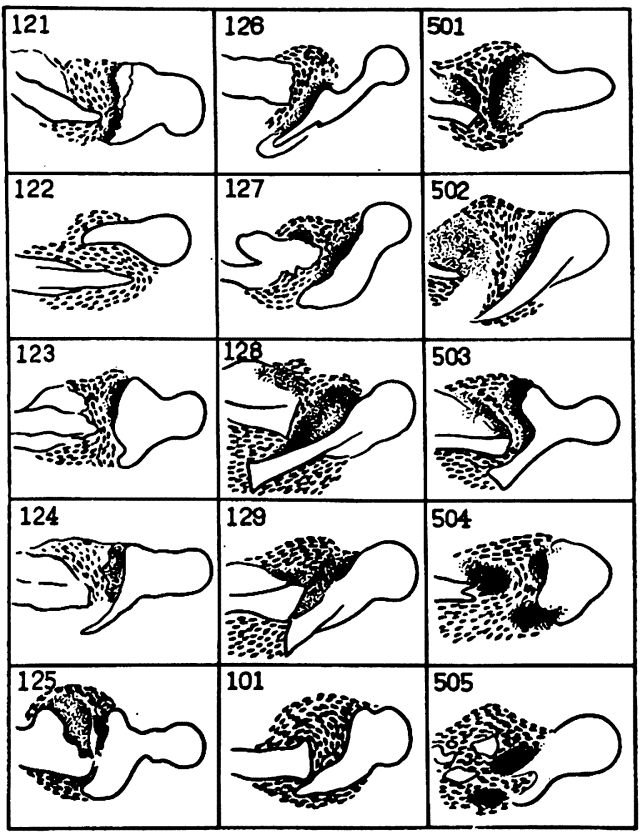

写真 101 週間後所見 小さな点一軟骨組織 太い点一線維性結合組䄉
Diagram of the repair of Subcondylar fractures in young rats. (2 weeks after operation.)

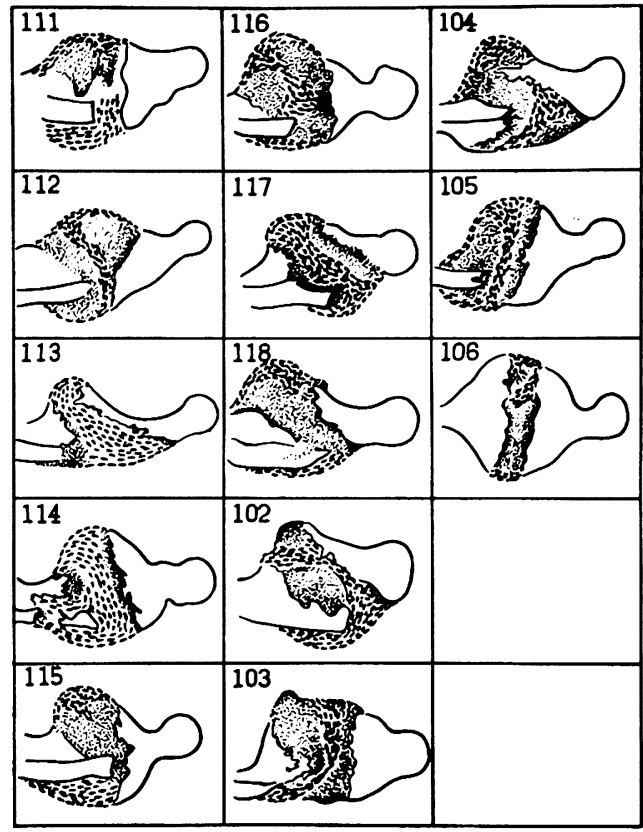

写真 112 週間後所見

Diagram of the repair of Subcondylar fractures in young rats. ( 3 weeks after operation.)

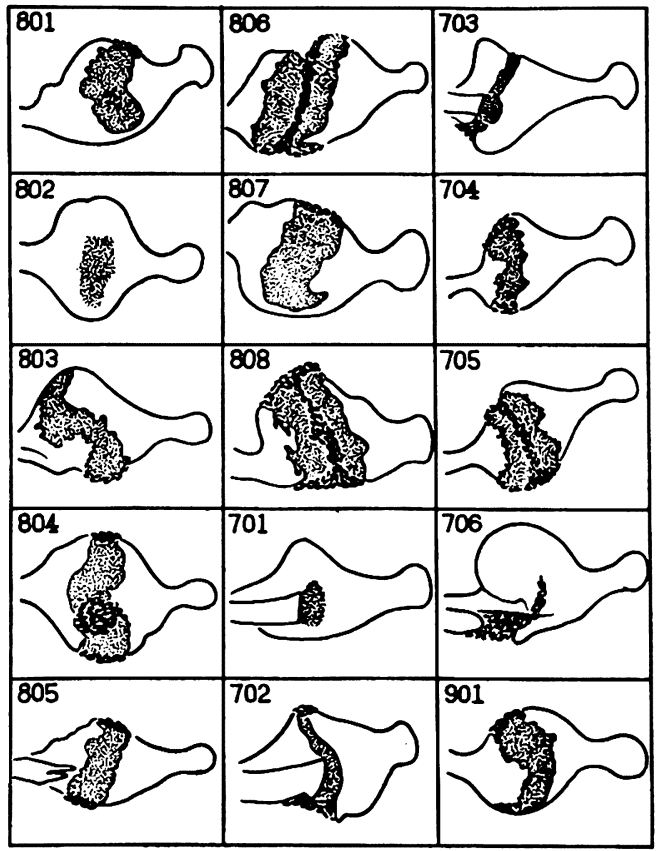

写真 12(a) 3 週間後所見 
Diagram of the repair of Subcondylar fractures in young rats. ( 3 weeks after operation.)

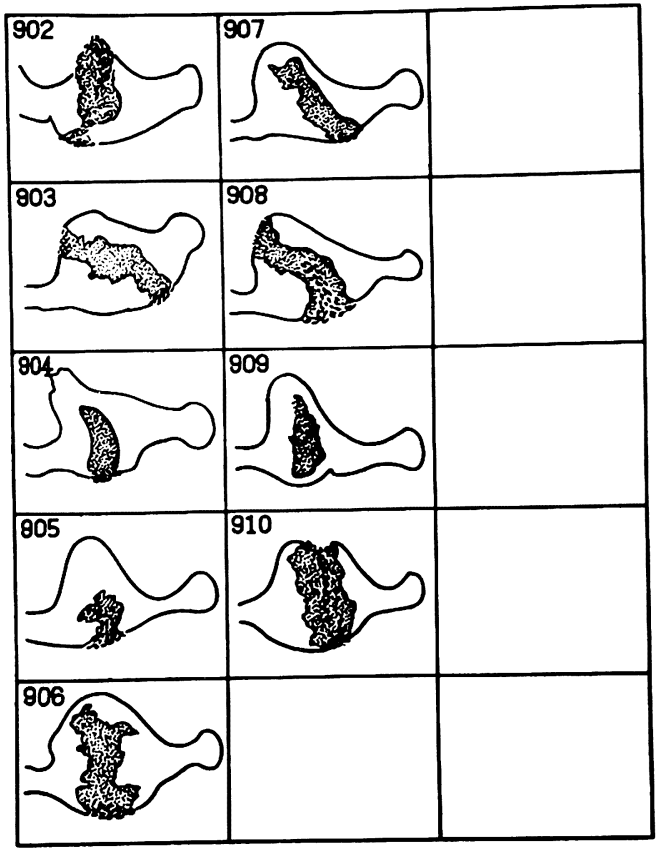

写真 12(b) 3 週間後所見

Diagram of the repair of Subcondylar fractures in young rats. (12 week after operation.)

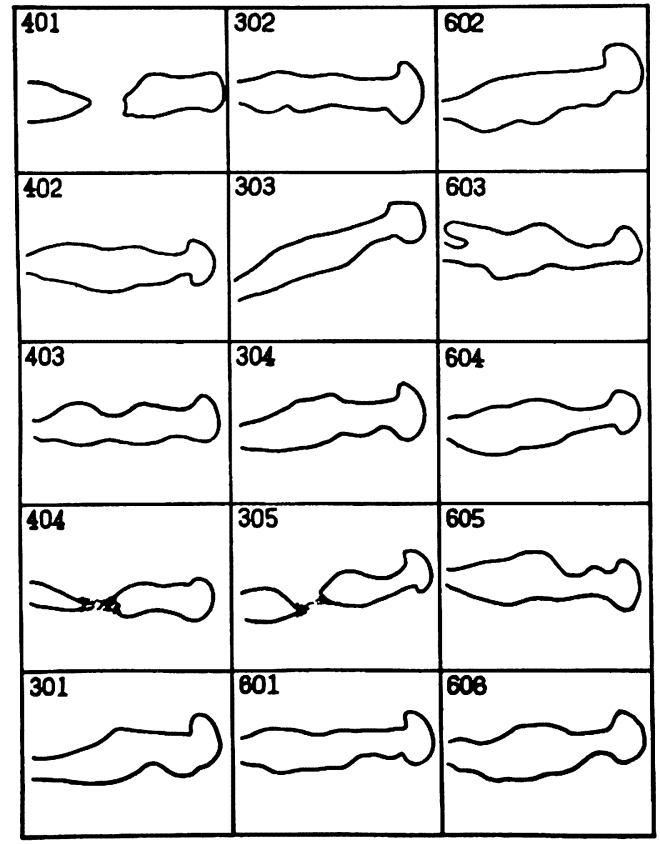

写真 13 12週間後所見
所もあった．術後 3 週目（写真12a， b ）においては， 瘤状に肥厚した骨折部は両骨折片に近い場所からの仮骨 形成により，新生骨梁が軟骨組織，線維性結合組織を包 合するがごとき像を現わしていた．術後12週目（写真 13）の模式図からは，症例401，404，305のごとき，い わゆる non union のものもあったが，骨性痛合の認め られるものでは全例ともその形態は不規則で, やや肥厚 を残しながらも顎関節突起の形態再生が認められた。

\section{考按}

今回著者らはラット顎関節突起に実験的骨折を若起し, 術後 1 週目， 2 週目， 3 週目， 12 週目における骨折治瘾 状態につき組織形態学的見地より経時的観察を行なった。 その結果，骨折片の偏位状態は多数例に扣いて骨体側 骨折片を定位置にし，下顎頭側骨折片断端が内方に向か った内方偏位を示していた。このことは，骨折片の偏位 か，骨折片に附着する筋肉の走向方向に一致することか らすれば，顎関節突起骨折に扣いても，下顎頭に附着し た外側翼突筋の前内方への収縮の結果, 下顎頭側骨折片 の内方偏位を見たといえよう。

内方偏位した下顎頭側骨折片内側，骨体側骨折片内側 に，術後 1 週目に著しい軟骨組織の出現が見られた。 こ のような場所では Endchondral ossification が活発に 行なわれ，すでに新生骨梁形成のなされている所も見ら れた. 一方 Intramembranous ossificiationによっても 新生骨形成のみられるところもあり，骨折修復像には同 時に異なった仮骨形成様式が観察された。この部の骨折 修復は, 1 週目という比較的早期に, Endchondral ossification, Intramembranous ossification などの仮骨 形成様式にて新生骨梁が出現し，骨形成が開始されるこ とがわかった. 3 週目にはすでに修復部の肥厚した新生 骨梁の内部改造が進み remodelling が活発であった. そして12週目では，骨折修復機転の 2 週目，3週目に認 められた骨折部の骨, 軟骨組織よりなる瘤状の著明な肥 厚は消失し，軟骨組織も消失し，わずかに肥厚した関節 突起として観察され，ほぼ正常に回復していた。

さて骨折の治療にあたっては，骨折片の整復，固定に よって解剖学的形態回復を図ることが必須の条件とされ ているが，本実験のごとく，整復，固定という操作を加 えない場合にも，骨折片の癒合，形態回復が見られた理 由として次の事項が推察される.すなわち本実験に使用 した動物が体重 $130 \mathrm{~g}$ 前後と成長期のものであったこと が推察されるとともに, Sarnat ${ }^{11)}$, Jolly ${ }^{12)}$ らが述べて いるごとく，下顎頭は下顎骨の発育センターであるがゆ えに，この部の骨折は組織形態学的には回復が容易であ ったのではないかと考えられる．また䫇関節周囲組織の 筋肉, 靱帯などの活動は, 骨折片の整復に役立つと共に 顎関節突起の形態を規定するような作用があるのではな いかと考えられた。 
骨折の治癒過程における骨折片断端部の組織構造は, 損傷時の時期によって異なるが，最終的には両骨折片の 骨性癒合によって連絡される。しかし損傷直後から骨性 癒合の完成までには，骨折片断端間隙部の凝血の器質化， 線維性仮骨の形成，骨性仮骨の形成，骨折片の骨性結合 の順に組織像の推移があり，顎関節突起骨折もこのカテ ゴリーの中で治痛が行なわれるが，本実験において認め られた特長的なことは先に述べたごとく，骨折片断端部 に打ける著明な軟骨組織の形成であった。

一般に骨折治癒過程に軟骨組織を含む仮骨形成が認め られることは周知のとおりであるが，本研究においては 軟骨形成がとくに顕著であった.

軟骨組織出現の理由としては, 骨折修復時の軟骨組織 の出現にはさまざまな見解があるが, Bourn ${ }^{13)}$ は osteogenic cell は循環系の回復が行なわれやすい環境にあ っては骨形成を行ならが，環境が適当でない場合にはそ れは軟骨形成を行ならであろらと説明する局所循環障害 について述べている，それに対し Krompecher ${ }^{14)}$ は， 骨折片に加わる物理的因子を，圧迫，索引，無作用に分 類し，骨組織の力学的適応により異なった組織反応が起 るのではないかと述べている. Sprinz ${ }^{5)}$ は実験的顎関節 突起骨折の報告の中で，内方に偏位した下顎頭骨折片と， 骨体側骨折片が咬筋および内側翼突筋の収縮により, 両 骨折片間吵組織が圧迫され，循環障害を生じる結果，軟 骨組織が出現するのではないかと述べている．著者らの 観察では，軟骨組織は特に両骨折片内方に見られ，外方 においても下顎頭側骨折片断端部，骨体側骨折片の一部 に術後 1 週目で早くも観察された. 2 週目になると, 内 万への増殖が活発になり瘤状に突出しており，3週目で は endchondral ossification, intramembranous ossification が旺盛に行なわれ, 軟骨組織の周辺部に新生骨 梁が出現し, 次第に内方に拡がり内部改造が行なわれて いた。

本来骨折片断端部の間葉性結合組織は Intramembranous ossification の方向にあるといわれている. しか し今回の実験では軟骨組織が出現したことから考えると， 芽組織はかならずしも intramembranous ossification の方向のみにあるとは限らず，時には endchondral ossification の方向に向く場合もあると考えられた理由と して次のようなことが考えられた。すすなわち手術による 組織破壊程度が大であったこと, Bourn ${ }^{13)}$, Krompecher ${ }^{14)}, \quad S p r i n z^{5)}$ が述べているごとき, 周囲組織に循環 障害を発生せしめたことなどが endchondral ossificationをらながしたとも考えられる.

今回の顎関節突起骨折の突験的研究においては, 骨折 治瘜過程に著明な軟骨組織の出現が認められたが, 本実 験においては, 骨折片の整復, 固定, 顎運動制限は行な わずして自由に顎運動を営なませたため, 治瘾経過中に 一時的な軟骨組織の出現があったのかも知れず，骨折片
の整復，固定による局所の安静を図った際の治㾔過程と の比較検討が必要であろう。

\section{結}

\section{論}

顎関節突起骨折の治癖方法には, 保存的療法, 外科的 療法がある.しかし顎関節突起は解剖学的に擷関節とい ら非常に複雑な運動をつかさとる部位であるがゆえに, さらにまた組織形態学的にも骨折治瘺過程が充分に解明 されていない現在，その選択に困惑させられることがあ る.このような観点から, 今回著者らはウイスター系ラ ットを使用し，実験的に罘関節突起骨折を若起し経時的 に組織形態学的治癒過程の観察を行なった. 術後 1 週目 には軟骨組織が特に雨骨折片断端部周辺の結合組織内に 軟骨組織の出現が認められた。 また少量の骨梁の新生も 認められた，軟骨組織はその後，次第に肥厚し，骨折片 に接した軟骨組織は骨·組織に置換し始め, endchondral ossification による仮骨形成が盛んであった。 また骨折 片の骨膜からも骨新生が起り intramembranous ossification も認められた。 3 週目になると，仮骨はますま す増大し骨改造機転が著明であった，12週目には，層板 構造，骨髄腔も完成し，正常部分とほぼ見分けがつかな いまでに骨改造が進んでいた，骨折治痛過程中の軟骨組 織の出現について種々諭議がなされているが充分に把握 されているとは言えない、今回の実験から骨折片断端間 隙に著明な軟骨組織の形成がみられたことは，両骨折片 の整復，固定を行なっていないため，断端の不適合とな り, 骨折片間隙への多量の結合組織が増生し, また自由 な顎運動により骨折片の安静が図られなかったため, intramembranous ossification と共に endchondral ossification の出現が多かったものと思われた. また成 長期動物の下顎頭では, 関節軟骨層は肥厚し, 発育期に あるため,この附近の組織には軟骨組織が旺盛なためで あるかも知れないと考えられた。

本論文の要旨は昭和 46 年 4 月第 25 回日本口肤科学会総会に おいて発表した.

\section{文献}

1) Eubanks, R. J. : Fractures of the neck of the condyloid process. J Oral Surg 22: 2851964.

2) Thoma, K.H. : Fractures and fracture dislocations of the mandibular condyle: a method for open reduction and internal Wiring and one for skeletal fixation with a report of thirty-two cases. J oral Surg $3: 31945$.

3) Robinson, M., and Yoon, C. : New onlay-inlay metal splint for immobilization of mandibular subcondylar fractures. Amer J Surg 100:845 1960.

4) Ole Gilhous Moe: Fractures of the mandibular condyle in the growth Period, Histologic and autoradiographic observation in the contralateral, nontraumatized condyle. Acta odontologica scandinavica. $29: 531971$.

5) Sprinz, R. : Divisions of the neck of the mandibular 
in rats. J Anat 101:765 1967.

6) Sprinz, R. : Healing of fractures of the neck of the mandibule in rats with detachment of the lateral pterygoid muscle. Arch oral Biol 15 : 12191970.

7) Anderson, M.F - Subcondylar fractures in young dogs. J Oral Surg 19:263 1965.

8) Walker, R.V : Traumatic mandibular condylar fracture dislocations. Amer J Surg 100:850 1960.

9) Boyne, R. J : Osseous repair and mandibular growth after subcondylar fractures. J oral Surg $25: 3001967$.

10）小野尊㓐, 福井正義, 島原政司, 横矢喬: 顎関節突起骨 折に関する実験的研究. 口科誌 $21: 11972$.
11) Sarnat, B. G : Development facial abnomalities facial pain and mandibular dysfunction. W. B. Saunders Co. 1969 , p. 83.

12) Jolly, $M$ : Condylectomy in the rat. An investigation of the ensuing repair process in the region of the temporomandibular articulation. Australian Dental Journal $6: 2431961$.

13) Bourne: The Biochemistry and Physiology of Bone. Academic press Inc. New York. 1956.

14) Krompecher:Die Knochenbildung. Gastav Fischer. Frankfurt. 1937. 